\title{
実験的結模症のINAH 誘導体による治療奏験
}

\author{
第一編 \\ Isonicotyl hydrazone glycuronolactone のマウスによる \\ 急性毒性試験並びそ実験的結核症の治療実験 \\ 風山大学医学部平木内科室（主任：平木 潔教授） \\ 山下 三代吉
}

[昭和 33 年 7 月 26 日受稿]

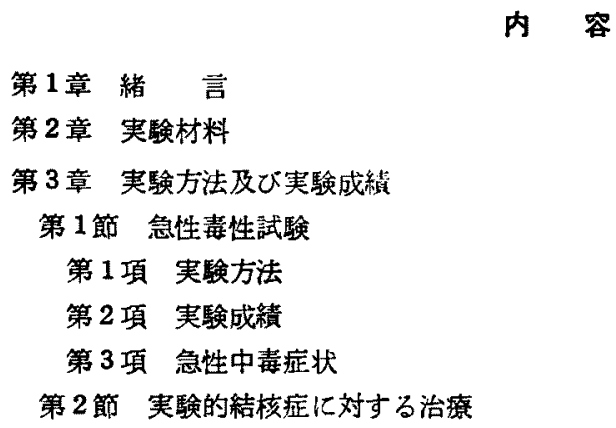

\section{第1章緒等}

結核治療剂の過去の歴史を顧みるとコっホがツべ リクリンを特効薬として発表して以来，幾多の無機 及び有機物質が特効薬として発表されたが，いつれ むその中に使用されなくなつた。

その理由は単に効果が無かつたというだけではな

く、種々の副作用が経験されたかからですある。

近時 Streptomycin (SM) が抗結核威として，輝

しく登場し, 次で Paraaminosalicylic acid (Pas) Thioacetazone (TB1) が発見され，更に1912 年 Isonicotinic acid hydrazide (INAH) が Meyeril) によつて合成された，以来 INAH を中とした広 範な研究沈よつて 1-isonicotinyl-2-isopropyl hydrazine (Marsild), 1-isonicotinyl-2-glucosyl hydrazine, Isonicotinsäure benzahl hydrazid (Isoteben), P-oxybenzahl isonicotinsäure hydrazone (Flavoteben), M-oxybenzahl isonicotinsäure hydrazon (Acroteben), P-chlorbenzahl isonicotinsäure hydrazon 等, 続々と INAH 誘導体が出現 し, 又最近 Peter18) 等は D-galactoronic acid isonicotinyl hydrazone が抗菌価が高く動物に対す

目次

第 1 項 INHG
1. 第一実驗
2. 第二実験

第 2 項 IHMS

第4 章 総括並びに考按

第 5 章 結 語

文献

る毒性は INAH より少いと紹介している，茲に私 は最委新しい INAH 誘導体の毒性試験並びに実験 的結核症の治療実験を行う機会を得たのでての成績 を報告する。

本研究の対家である Isonicotyl hydrazone de la glycuronolactone (INHG) は 1952 年フランスの Passedouet17) 等によつて INAH とグルクン酸 (ラクトン型）との維合物として合成され，引続き Brouet3）等によりラッテ，モルモっトの実験的結 核症に対する治㙩実験が行われ，その進展を阻止す るといわ机ているが，之は単に剖検所見に基くもの であつて，斯加る治療実験に必要不可欠6䑏器結核 菌定冒培领実験を久いでいるので，直ちにその効力 の正確さを云々する事は出来ない．

そとで私は今回本邦に於て製造せられた本薬剂を 使用し，改めてマウスによる毒性試験及びマウス実 験的結核症に対する笮密なる定量培溇実験による治 療効果を檢討した。

なお本研究に於ては対照として INAH 及びその 誘䓕体である IHMS についても春験し，INHG 上 比較娭討した。 


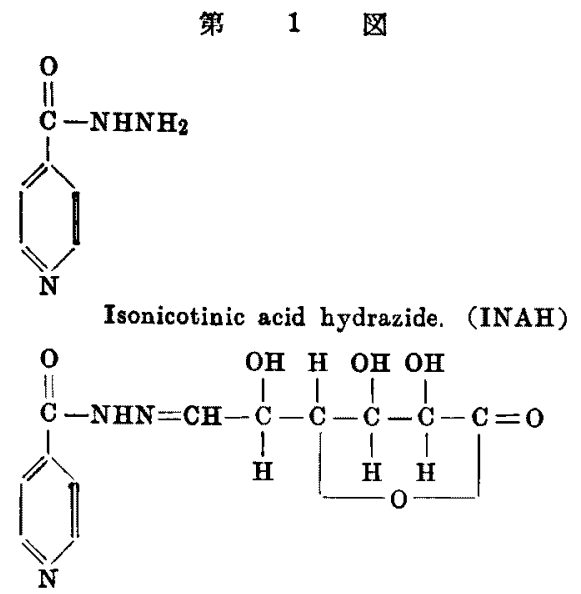

Isonicotyl hydorazone gly curonolactone. (INHG)<smiles></smiles>

Isonicotinyl hydrazid methansulfonate.

(IHMS)

\section{第 2 童 実 酫 材 料}

i）薬剂：両楽剂の化学構造は図に示す通り で両者之す無景の色色乃至類白色の結晶性粉木であ る. INHG は1モルの中に INAH が44.62\%含ま

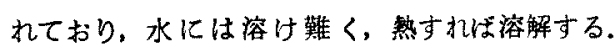
IHMS は INAH が54.196含まれ水によく溶解し， アルコールには僅かに溶け，エーテルには極めて䨅 溶で，水溶液は殆んど中性である，融解点はINHG $169 \sim 170^{\circ} \mathrm{C}$, IHMS は166 168 ${ }^{\circ} \mathrm{C}$ INHG が僅 加汇高い.

ii）実験動物：INHG，IHMS の基磷実験， 即ち急性毒性試験及び抗結核剂としての効力判定に 夫々 $10 . \mathrm{g}$ 及び $12 \mathrm{~g}$ 前後のマウスを使用した.

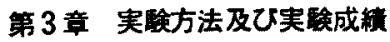

\section{第 1 節 急性毒性誠験}

\section{第1 項 実験方法}

体重 $10 \mathrm{~g}$ のマウスを選び，その150匹を25群に 分け, INHG, IHMS は水溶液とし $60^{\circ} \mathrm{C} 30$ 分 3 回 減菌後，夫↔の所要量を総て $0.2 \mathrm{cc}$ 中に含ましめ るようにして使用した。
薬物投与量の決定： 先づ予備実験として 3 匹宛 の4群を作り，INHG，IHMS が夫々500 mg/kg, $2000 \mathrm{mg} / \mathrm{kg}$ の量を皮注した処，500 mg/kg 群は 全部生存, $2000 \mathrm{mg} / \mathrm{kg}$ 群は全て死亡する事を整認 したので，之を上下の薬量として本実験の使用量を $500 \mathrm{mg} / \mathrm{kg}, 1000 \mathrm{mg} / \mathrm{kg}, 1500 \mathrm{mg} / \mathrm{kg}, 2000 \mathrm{mg} / \mathrm{kg}$ と定めた。な招経口投与の場合は本実験の成續によ つて $2500 \mathrm{mg} / \mathrm{kg}$ を追加した。

本実験：前記水资液 $0.2 \mathrm{cc}$ をマウスの大犁皮 下に注射し，又手製マウス経口投与猓で確実に食道 に薬液が入るようにして経口投与した。比较の意味 でINAH あ同様に実施した。

\section{第 2 項 実験成績}

判定は 5 時間後上し第 1 表は各濃度に於けるマウ スの死亡数を示してものて，皮下注射の場合 $500 \mathrm{mg} / \mathrm{kg}$ では全部生存し，濃度が增すに従い死

第 1 表 INAH 平均致死置

\begin{tabular}{cc|c|c|c|c|c}
\hline \hline 方法 & $1 \mathrm{mg}$ & $1.5 \mathrm{mg}$ & $2 \mathrm{mg}$ & $2.5 \mathrm{mg}$ & Ld (50) \\
\hline 皮 & 下 & $0 / 6$ & $4 / 6$ & $6 / 6$ & & $141 \mathrm{mg} / \mathrm{kg}$ \\
経 & $\square$ & $0 / 6$ & $2 / 6$ & $5 / 6$ & $6 / 6$ & $167 \mathrm{mg} / \mathrm{kg}$
\end{tabular}

INHG 平均致死量

\begin{tabular}{cc|c|c|c|c|c|c}
\hline \hline 年法 & $5 \mathrm{mg}$ & $10 \mathrm{mg}$ & $15 \mathrm{mg}$ & $20 \mathrm{mg}$ & $25 \mathrm{mg}$ & $\mathrm{Ld}(50)$ \\
\hline 皮 & 下 & $0 / 6$ & $2 / 6$ & $5 / 6$ & $6 / 6$ & & $1167 \mathrm{mg} / \mathrm{kg}$ \\
経 & 口 & $0 / 6$ & $1 / 6$ & $3 / 6$ & $5 / 6$ & $6 / 6$ & $1500 \mathrm{mg} / \mathrm{kg}$
\end{tabular}

IHMS 平均致死最

\begin{tabular}{|c|c|c|c|c|c|c|c|}
\hline 方流 & & $5 \mathrm{mg}$ & $10 \mathrm{~m}$ & $15 \mathrm{mg}$ & $20 \mathrm{mg}$ & $25 \mathrm{mg}$ & $\mathrm{Ld}(50)$ \\
\hline 防 & 下 & $0 / 6$ & $3 / 6$ & $5 / 6$ & $6 / 6$ & & $1083 \mathrm{mg} / \mathrm{kg}$ \\
\hline 経 & ロ & $0 / 6$ & $2 / 6$ & $4 / 6$ & $5 / 6$ & $6 / 6$ & $1333 \mathrm{mg} / \mathrm{kg}$ \\
\hline \multicolumn{8}{|c|}{ 証，使用㔚物：10瓦のマウス } \\
\hline \multicolumn{8}{|c|}{ 判 定 - 5 時間 } \\
\hline \multicolumn{8}{|c|}{ 計 算：面皘法 } \\
\hline \multicolumn{8}{|c|}{ 分子. 死亡数 } \\
\hline \multicolumn{8}{|c|}{ 分 ：使用マウス数 } \\
\hline
\end{tabular}

亡数む增大し，2000 mg/kg では全部死亡し，経口 投与百同梾に $2500 \mathrm{mg} / \mathrm{kg}$ で全部死亡した. 之を 毒㨫曲線で示すと第 2 四の如くなり，之より面植 法で算定すると平均致死星は INHG 皮下注射 $1167 \mathrm{mg} / \mathrm{kg}$ ，経口投与 $1500 \mathrm{mg} / \mathrm{kg}$, IHMS 皮下 $1083 \mathrm{mg} / \mathrm{kg}$, 経口 $1333 \mathrm{mg} / \mathrm{kg}$ であつた。同腈に 行つた INAH Ld (50) 皮下 $141 \mathrm{mg} / \mathrm{kg}$, 経口 
第更

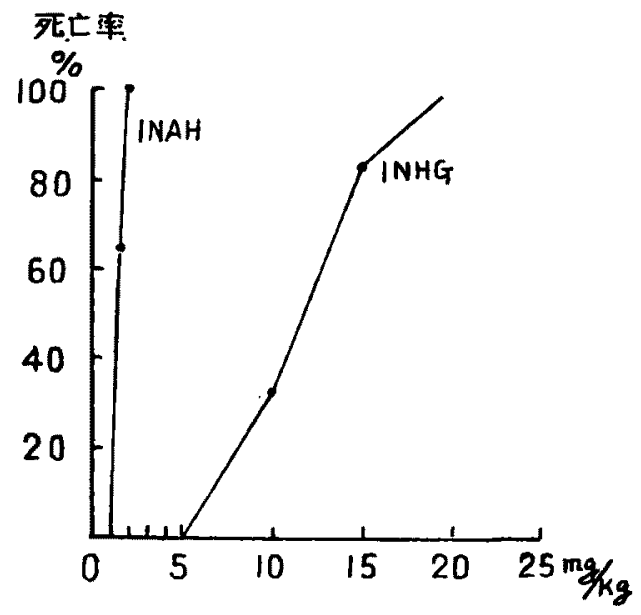

INHG. INAH 皮注毒性曲線

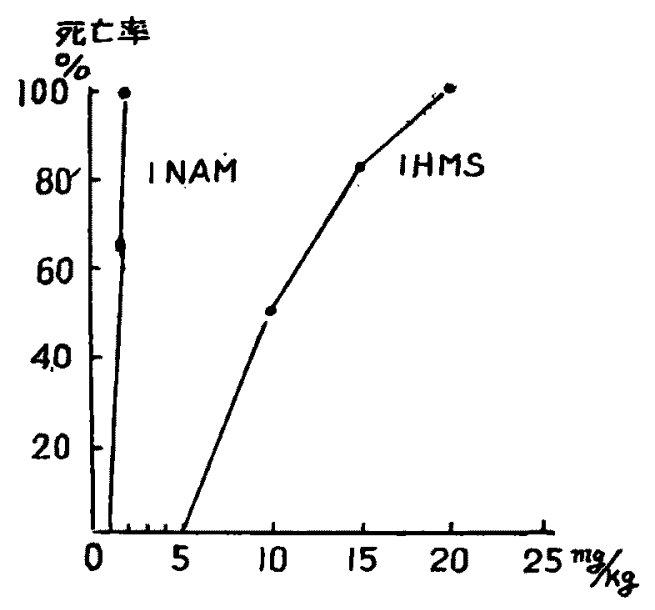

IHMS. INAH 皮注毒性曲線

$167 \mathrm{mg} / \mathrm{kg}$ に比较すると INHG, IHMS 共 $7 \sim 8$ 倍になり，従つて毒性はINAH の 1/7〜1/8 であ 万.

第 3 項 急性中毒症状

INHG INAH の症状に似ており早いもので 30分, 遅いものです 4 時間以内に疾走, 跳踓等の運 動過敏乃至は興畠状を示し，次で四肢の間代性强直

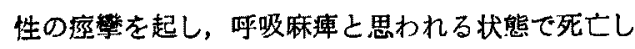
た，その内，興秵状から回復したマウスは死亡を免 机た。

IHMS : 注射後興雄（中には促進せる大呼吸を なするの等ありて，間代性の庭を起し，強直性の 状態になると間もなくマウスは死亡した。

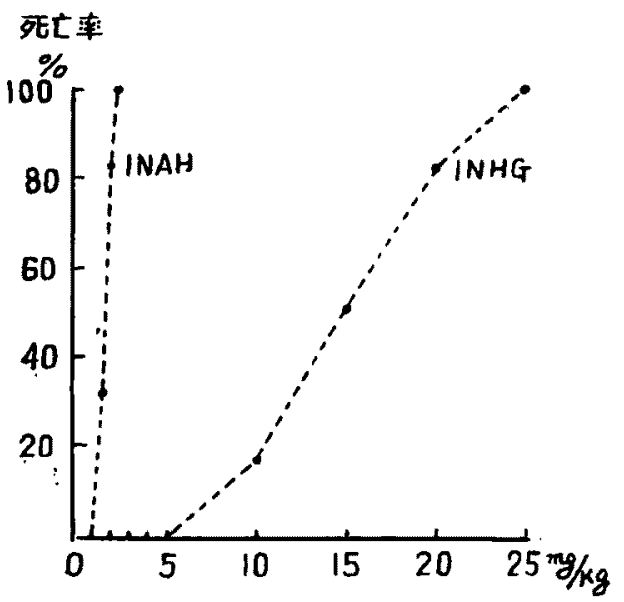

INHG. INAH 絓口毒性曲線

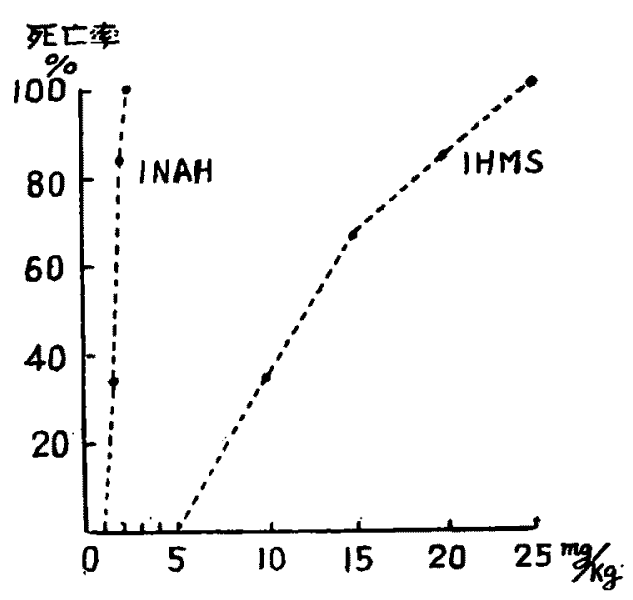

IHMS. INAH 経口毒性曲線

INHG, IHMS 共に注射後 2 時間以内に死亡する もの多く，それ以後は 5 時間までに少数死亡し，次 後死亡なく，24時間後には外観的に摄食普通，軍動 活溌で変化ないようであつた。

第 2 節 実験的結核症に対する治療

\section{第 1 項 INHG}

末だ正雅な野物実験の行われてない INHG が有 効か否か, 又 $\mathrm{INAH}$ との比較についてマウスを結 校に感染せしぬて第一，第二実験を行つた。

1. 第一実験

1) 実験方法

マウスは体重 $12 \mathrm{~g}$ 前後の雄性84匹を使用し，1 群を6匹宛とした，接種菌は人型結核囷 $\mathrm{H}_{37} \mathrm{RV}$ 
を用い，3务小川培地で 2 週間培鿾した集落を取り， ガラス玉入り硬算コルヘンンで手振法により $15 \mathrm{mg} / \mathrm{cc}$

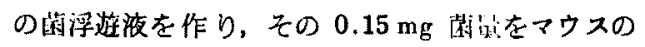

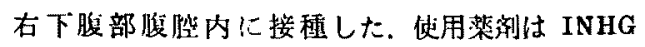
$1 \mathrm{mg}(83 \mathrm{mg} / \mathrm{kg}), \quad 3 \mathrm{mg}(250 \mathrm{mg} / \mathrm{kg}), \quad 7 \mathrm{mg}$ $(583 \mathrm{mg} / \mathrm{kg})$ であり，実験群としては之等の各群 と対照の非治療群共で 4 群を編成した。治潦は蒛接 種翌日より速日投与とし，期間は 3 週及び 6 週間と した，楽郕の投与に当つては水溶液とし，所要量を $0.1 \mathrm{cc}$ 中に含ましわるようにし, 毎日 1 回マウス の大䭆皮下に注射した。

治暑開始 3 週後各群上り 3 匹宛を唇殺し肺, 用,
脾の肉眼的病変の程度及び結核結節の多少を検し， その内各群 2 匹宛については肺，肝，脾の葴器結核

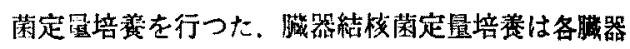
をガラスホモダナイザーで磨砕し，平等乳剂となし 4 \%菏惊ソーダで50，500，5000倍に稀釉し，その $0.1 \mathrm{cc}$ を 3 \%小川培地に夫ネ3 本つつ培養し, 週 1 回躬卵器より取り出して生した集落数を算定し 6 週間観祭したが，判定は4 週目に行つた。

治療 6 週後にも残り半数を同槏に剖強し処理した。 2) 実験成綪

肉眼的剖検所見 . 治療開始 3 週後に屠殺したマ ウスの各筥器の剖検所見は第 2 表に示した通りで肉

第 2 表 INHG により 3 週間治療せるマゥスの肉眼的剖検所見

\begin{tabular}{|c|c|c|c|c|c|c|c|c|c|c|c|c|c|c|}
\hline \multirow{2}{*}{\multicolumn{3}{|c|}{$=\frac{\text { 薬 }}{\text { No. }}$}} & \multicolumn{3}{|c|}{$1 \mathrm{mg}$} & \multicolumn{3}{|c|}{$3 \mathrm{mg}$} & \multicolumn{3}{|c|}{$7 \mathrm{mg}$} & \multicolumn{2}{|c|}{ 対 } & 照 \\
\hline & & & 肺 & 肝 & 脾 & 肺 & 肝 & 脾 & 肺 & 肝 & 脾 & 肺 & 肝 & 脾 \\
\hline 3 & 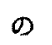 & 1 & - & - & + & - & - & - & - & - & - & + & - & $H$ \\
\hline 3 & $の$ & 2 & \pm & - & - & - & - & - & - & - & - & \pm & - & + \\
\hline 3 & Ф & 3 & - & - & - & - & - & - & - & - & - & + & \pm & H \\
\hline
\end{tabular}

眼的病変をとストクラム法で記载した． 即ち，対照 群には著明な結核性病変が認められ，特に脾に於て 著しく、INHG $1 \mathrm{mg}$ 治療群には軽度の病変が認 められ、 $3 \mathrm{mg}, 7 \mathrm{mg}$ 治療群には殆んど認められな
かつた.

治療開始 6 週後に屡䊏した剖検所見は表の如くで, $7 \mathrm{mg}$ 治療群以外には病変を認めたが, $3 \mathrm{mg}$, $1 \mathrm{mg}$ 治瘄群は極めて僅かであつた。

第 3 表 INHG てより 6 週間治療せるマウスの肉眼的部検所見

\begin{tabular}{|c|c|c|c|c|c|c|c|c|c|c|c|c|c|c|}
\hline \multirow{2}{*}{\multicolumn{3}{|c|}{$\begin{array}{c}\text { 薬 } \\
\text { No. 膱 } \\
\end{array}$}} & \multicolumn{3}{|c|}{$1 \mathrm{mg}$} & \multicolumn{3}{|c|}{$3 \mathrm{mg}$} & \multicolumn{3}{|c|}{$7 \mathrm{mg}$} & \multicolumn{2}{|c|}{ 対 } & 照 \\
\hline & & & 肺 & 肝 & 脾 & 肺 & 肝 & 脾 & 肺 & 旰 & 脾 & 肺 & 肝 & 脾 \\
\hline 3 & の & 4 & - & - & \pm & - & - & - & - & - & - & \# & \pm & \# \\
\hline 3 & $\infty$ & 5 & - & + & - & - & - & \pm & - & - & - & $H$ & - & $H$ \\
\hline 3 & $の$ & 6 & \pm & \pm & - & - & + & - & - & - & - & + & - & $H$ \\
\hline
\end{tabular}

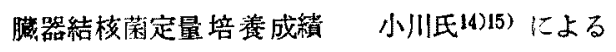
方法で閶器 $1 \mathrm{mg}$ の生菌数を数字で表わしたのが第 4 表である， $1 \mathrm{mg} ， 3 \mathrm{mg}$ 治療群共そ㣗それ対照 に比して庣器 $1 \mathrm{mg}$ 中の菌量少く, $7 \mathrm{mg}$ 治療群は
$1 \mathrm{mg}$ 治療群の順で有效である.又 3 週よりは6週 の方がより有効な数值を示している. 以上の事柄よ り実験的マウス結核症に INHG は充分の抗菌力を 表わしている事が分る.

肺，訮，脾とも全て陰性であり，次で $\mathbf{3 m g}$ 治療群，

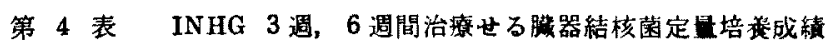

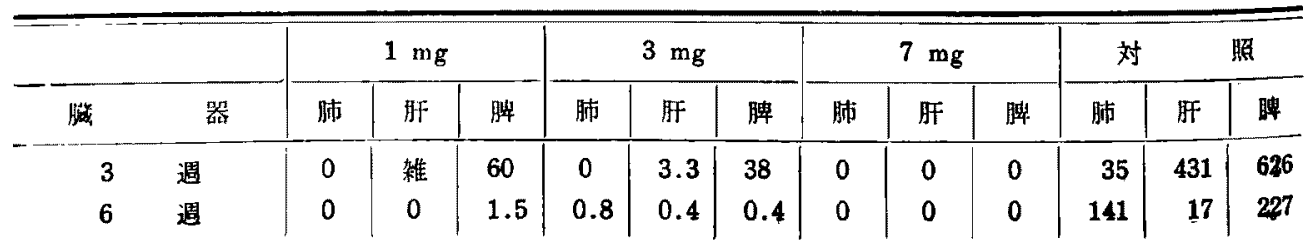

(腈器 $1 \mathrm{mg}$ 中コロニー数) 
2. 第二実験

1）実験方法

第一奏呤て INHG の有効なる事を立证し得たの で, INHGとINAH の投与蛋を種な変える事によ りINAHと効果の比校を見んとして本実験を行つた。 投与是は第 5 表の如くにし，1群 6 匹の10群に編成 を行い，動物，菜，薬同等は第一奏験と同様にした。 第 5 表 INHG，INAH 皮下注射量

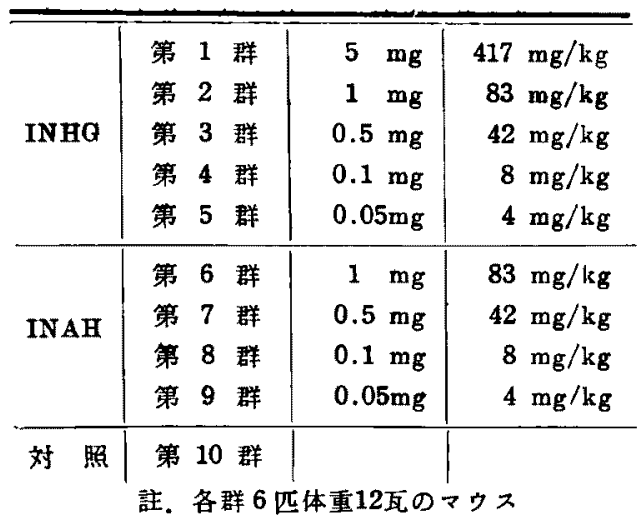

2) 実験成績

体重の変動： 第 6 表及び第 3 図は各群の 3 週及

第 6 表 INHG, INAH で 3 週，6週間 治潦せるマウスの体重の推移

\begin{tabular}{c|cc|cc|c}
\hline \hline & 祭 & 量 & 3 & 䓢 & 6 遇 \\
\hline \multirow{6}{*}{ INHG } & $5 \mathrm{mg}$ & $-0.66 \mathrm{~g}$ & $-2.0 \mathrm{~g}$ \\
& $1 \mathrm{mg}$ & $+1.4 \mathrm{~g}$ & $+2.0 \mathrm{~g}$ \\
& $0.5 \mathrm{mg}$ & $+0.6 \mathrm{~g}$ & $+4.0 \mathrm{~g}$ \\
& $0.1 \mathrm{mg}$ & $+2.0 \mathrm{~g}$ & $+3.5 \mathrm{~g}$ \\
& $0.05 \mathrm{mg}$ & $-1.33 \mathrm{~g}$ & $+1.5 \mathrm{~g}$ \\
\hline \multirow{6}{*}{ INAH } & 1 & $\mathrm{mg}$ & $-1.0 \mathrm{~g}$ & $+1.5 \mathrm{~g}$ \\
& $0.5 \mathrm{mg}$ & $-2.74 \mathrm{~g}$ & $+1.0 \mathrm{~g}$ \\
& $0.1 \mathrm{mg}$ & $+0.33 \mathrm{~g}$ & $+2.5 \mathrm{~g}$ \\
& $0.05 \mathrm{mg}$ & $-1.5 \mathrm{~g}$ & $+3.0 \mathrm{~g}$ \\
\hline \multirow{6}{*}{ 対 } & 照 & $+0.5 \mathrm{~g}$ & $+2.66 \mathrm{~g}$
\end{tabular}
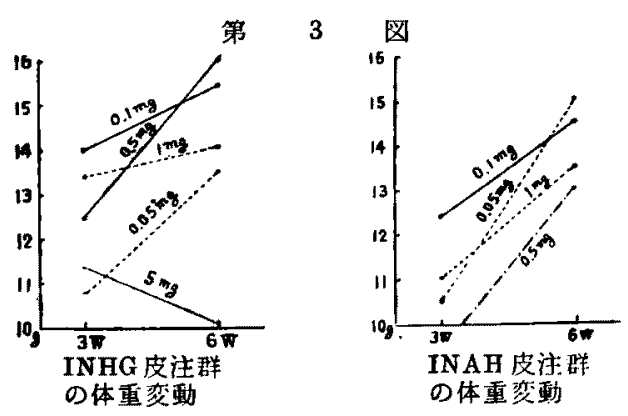

び 6 週の平均体重より当初の体重を差引いた数值で ある. 治療 3 週目に於て INHG 群は既に体重增加 が認められ，特に INHG $1 \mathrm{mg}$ 投与群が著しく, 6 週目に於ては $0.5 \mathrm{mg}$ 投与群 $(+4.0 \mathrm{~g}), 0.1 \mathrm{mg}$ 投与群 $(+3.5 \mathrm{~g}) ， 1 \mathrm{mg}$ 投与群 $(+2.0 \mathrm{~g}), 0.05 \mathrm{mg}$ 投与群( $+1.5 \mathrm{~g})$ の順に夫々体重增加が認められる. 一方 INAH 群は 3 週目には体重增加は顕著でなく 6 週目に於て INAH $0.05 \mathrm{mg}$ 投与群 $(+3.0 \mathrm{~g})$, $0.1 \mathrm{mg}$ 投与群 $(+2.5 \mathrm{~g})$ ，1 $\mathrm{mg}$ 投与群 $(+1.5 \mathrm{~g})$ ， $0.5 \mathrm{mg}$ 投与群 $(+1.0 \mathrm{~g})$ と增加を見ている。なお INHG $5 \mathrm{mg}$ 投与群に3 週で $(-0.7 \mathrm{~g}), .6$ 週で(一 $2.0 \mathrm{~g})$ の体重减少を認めるが，之は大量投与によ る慢性中毒のためてはないかと思われる. INHG 群と INAH 群では前者の方が体重增加は明らかに 勝つているといえる.

脾重の変動：静注接種マウスの脾に於ては感染 後次第に腫脹し，3週前後で $2 \sim 3$ 倍の大きさにな り，以後次第に減退する之岩崎8)等はいつている。 このように脾が結核感染が重篤はるにつれて, 正確 第 7 表脾重の比较

\begin{tabular}{|c|c|c|c|}
\hline 薬 名 & 薬量 & 週 & 6 \\
\hline INHG & $\begin{array}{c}5 \mathrm{mg} \\
1 \mathrm{mg} \\
0.5 \mathrm{mg} \\
0.1 \mathrm{mg} \\
0.05 \mathrm{mg}\end{array}$ & $\begin{array}{r}80 \mathrm{mg} \\
110 \mathrm{mg} \\
60 \mathrm{mg} \\
60 \mathrm{mg} \\
135 \mathrm{mg}\end{array}$ & $\begin{array}{r}95 \mathrm{mg} \\
150 \mathrm{mg} \\
35 \mathrm{mg} \\
100 \mathrm{mg} \\
83 \mathrm{mg}\end{array}$ \\
\hline INAH & $\begin{array}{c}1 \mathrm{mg} \\
0.5 \mathrm{mg} \\
0.1 \mathrm{mg} \\
0.05 \mathrm{mg}\end{array}$ & $\begin{array}{l}90 \mathrm{mg} \\
52 \mathrm{mg} \\
44 \mathrm{mg} \\
35 \mathrm{mg}\end{array}$ & $\begin{array}{l}82 \mathrm{mg} \\
75 \mathrm{mg} \\
95 \mathrm{mg} \\
95 \mathrm{mg}\end{array}$ \\
\hline 対 & 照 & $70 \mathrm{mg}$ & $87 \mathrm{mg}$ \\
\hline
\end{tabular}

に增量するものであり，同時にマウス個体差の䦕題 が然け机ば，治蟟楽の種類，投与晊の多け，治療期 間の長短等と脾重との間に何らかの閔聯性がある訳 であろう，而し本実験では腹腔内接種のためか，各 薬置間の差が僅かなためか不明であるか，一定の傾 向がこの場合現われなかつた。

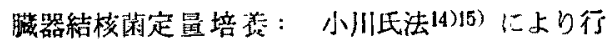
つた成嚗は第 8 表の如くて，数储は各群夫々 2 匹の 平均值である. INHG では $0.1 \mathrm{mg}$ 群, $0.05 \mathrm{mg}$ 群の肝，脾上り集落発南を認施れるも6 週治療後

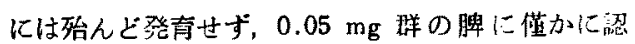
められるに過ぎい。一方 INAH は0.1 mg群, 


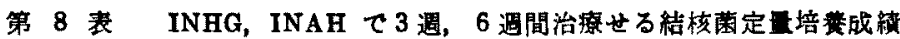

\begin{tabular}{|c|c|c|c|c|c|c|c|c|c|c|c|c|c|c|c|c|c|c|}
\hline \multirow{2}{*}{ 蒋 } & \multirow{2}{*}{ 名 } & \multirow{2}{*}{ 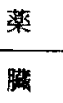 } & \multirow{2}{*}{$\frac{\text { 量 }}{\text { 器 }}$} & \multicolumn{3}{|c|}{$5 \mathrm{mg}$} & \multicolumn{3}{|c|}{$1 \mathrm{mg}$} & \multicolumn{3}{|c|}{$0.5 \mathrm{mg}$} & \multicolumn{3}{|c|}{$0.1 \mathrm{mg}$} & \multicolumn{3}{|c|}{$0.05 \mathrm{mg}$} \\
\hline & & & & 肺 & 肝 & 脾 & 肺 & 酎 & 腄 & 肺 & 旰 & 脾 & 肺 & 朋 & 脾 & 陠 & 腇 & 脾 \\
\hline \multirow{2}{*}{\multicolumn{2}{|c|}{ INHG }} & 3 & 䓢 & 0 & 0 & 0 & 0 & 0 & 0 & 0 & 0 & 0 & 0 & 0.2 & 50 & 0 & 0 & 116 \\
\hline & & 6 & 遌 & 0 & 0 & 0 & 0 & 0 & 0 & 0 & 0 & 0 & 0 & 0 & 0 & 0 & 0 & 1.2 \\
\hline \multirow{2}{*}{\multicolumn{2}{|c|}{ INAH }} & 3 & 䓢 & & & & 0 & 0 & 0 & 0 & 0.26 & 0 & 0 & 14 & 0 & 0 & 0.3 & 40 \\
\hline & & 6 & 週 & & & & 0 & 0 & 0 & 0 & 0 & 0.6 & 0 & 0 & 0 & 0 & 0 & 0 \\
\hline
\end{tabular}

\begin{tabular}{|c|c|c|c|c|c|c|}
\hline & & 䑏 & 器 & 肺 & 肝 & 脾 \\
\hline \multirow{2}{*}{ 対 } & \multirow{2}{*}{ 照 } & 3 & 週 & 0 & 0.17 & 107 \\
\hline & & 6 & 邅 & 0 & 2.5 & 40.2 \\
\hline
\end{tabular}

$0.05 \mathrm{mg}$ 群の肝, 脾に認められるる，INHG 群よ り程度は少く，6週後には認め嚾い，INHG と INAH の成精を比較すると $0.1 \mathrm{mg}, 0.05 \mathrm{mg}$ 群 共明らかに同展ではINHG が少く少る事が分る。

マウスの死亡数：本実験に於ては表の如くで INHG は $5 \mathrm{mg}$ 群に2 2 ，他の群では 1 匹宛 6 週の 害験完了までに死亡し，INAHは $1 \mathrm{mg}, 0.5 \mathrm{mg}$ 群は夫ょ 2 匹宛，残りの群は 1 匹宛死しし，奶照群

$$
\text { 第 } 9 \text { 表 } 6 \text { 週までのマウス死亡数 }
$$

\begin{tabular}{c|c|c|c|c|c}
\hline \hline 量 & $5 \mathrm{mg}$ & $1 \mathrm{mg}$ & $0.5 \mathrm{mg}$ & $0.1 \mathrm{mg}$ & $0.05 \mathrm{mg}$ \\
\hline INHG & 3 & 1 & 1 & 0 & 1 \\
INAH & & 2 & 2 & 1 & 1 \\
\hline 対 照 & & \multicolumn{3}{|c}{0}
\end{tabular}

には死亡を見なかつた. INHG $5 \mathrm{mg}$ 投与群の死亡 は大翼投与である故別しして，INHG の同一量の 群之比較して INHG の少い事は，之も本剂の㱟性 の小なる事の一端を示しているのである。

薬剂耐性： 6 週治療後に於ける耐性菌出現の有 無は INHG 1,10,100 $\gamma / \mathrm{cc}$ 添加小川培地飞 $0.1 \mathrm{mg}$ 群, $0.05 \mathrm{mg}$ 群の脾乳剂を接種培羡したが，短期 間治療及び楽量の少いためか，耐性菌の出現をみる に至らなかつた。
第 10 表 INHG 6 週治療後の培羡成綪

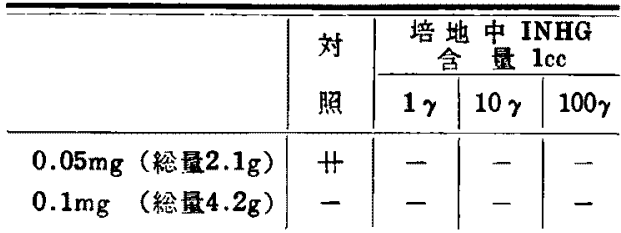

註。材料 脾エムルキオン

培地 小川耐性培地

\section{第 2 項 IH MS}

\section{1) 夆験方法}

体重 $12 \mathrm{~g}$ 前後のマウスに人型結校菌 $\mathrm{H}_{37} \mathrm{Rv}$ $0.15 \mathrm{mg}$ を腹沿内に接種し，翌日より皮下及び経 口投与を開始した。、ウスは各群 6 匹宛 9 群に編成 し第I，II群は IHMS 皮下及び経口夫ょ $1 \mathrm{mg}$ ，第 VI，䀑群はINAH 皮下及び経口夫^ $1 \mathrm{mg}$, 第XX群 は非治癔対照群とした，治療は連日投与とし，期間 は 3 及び 6 週間しした。なお 3 週間後より各群とも 投薬量を半減した，又 3 週と 6 週に夫々半数づつ剖 検定量培羡を行つた。

\section{2) 寒鞳成績}

肉眼的剖検所見：（表略） 3 匹宛の 3 週及び 6 週 の剖検に於て，各縢器の病変は対照群の顕著な事は 勿論て，治療群の内 IHMS $1 \mathrm{mg}$ 群，INAH $1 \mathrm{mg}$ 経口群に枝度の病変が見られ, IHMS $3 \mathrm{mg}$ 群, IHMS $7 \mathrm{mg}$ 群には病変は認められなかつた。

䑏器結核菌定是培瀁： 3 週及び 6 週後の肺, 肝, 脾の培港成績は第11表の如く，各群とも 3 週及び 6 週後何れも培養陰性であるが，唯IHMS $1 \mathrm{mg}$ 経口

第 11 表 IHMS で 週，6週間治療せる結核菌定最培養成鈢

\begin{tabular}{|c|c|c|c|c|c|c|c|c|c|c|c|c|c|c|c|c|c|c|c|c|c|c|c|c|}
\hline 群 & \multicolumn{6}{|c|}{$1 \mathrm{mg}$ INAH } & \multicolumn{6}{|c|}{$1 \mathrm{mg}$ IHMS } & \multicolumn{6}{|c|}{$3 \mathrm{mg}$ IHMS } & \multicolumn{6}{|c|}{$7 \mathrm{mg}$ IHMS } \\
\hline 方 法 & 皮 & & & 経 & & ロ & 皮 & & F & 释 & & ㅁ & 皮 & & 下 & 絓 & & 口 & 皮 & & 下 & 経 & & 口 \\
\hline 䏒 器 & 脾 & 旰 & 肺 & 脾 & 䀒 & 肺 & 脾 & 肝 & 肺 & 脾 & 腇 & 肺 & 輣 & 肝 & 肺 & 脾 & 肝 & 肺 & 脾 & 肝 & 肺 & 脾 & 肔 & 肺 \\
\hline 3 週 & 0 & 0 & 0 & 0 & 0 & 0 & 0 & 0 & 0 & $17.9^{\prime}$ & 8.4 & 0.4 & 0 & 0 & 0 & 0 & 0 & 0 & 0 & 0 & 0 & 0 & 0 & 0 \\
\hline 6 㥜 & 0 & 0 & 0 & 0 & 0 & 0 & 0 & 0 & 0 & 2.0 & 0.6 & 0 & 0 & 0 & 0 & 0 & 0 & 0 & 0 & 0 & 0 & 0 & 0 & 0 \\
\hline
\end{tabular}




\begin{tabular}{|c|c|c|c|c|}
\hline \multicolumn{2}{|c|}{ 群 } & \multirow{2}{*}{ 対 } & & \multirow{2}{*}{ 照 } \\
\hline 方 & 法 & & & \\
\hline 戥 & 器 & 䡟 & 旰 & 肺 \\
\hline 3 & 週 & $\infty$ & $\infty$ & 35 \\
\hline 6 & 䓢 & $\infty$ & 16.9 & $H$ \\
\hline
\end{tabular}

投与群に歲器 $1 \mathrm{mg}$ 当り表の如き価が出るす6 週後 には著明に減少している，即ち，IHMS は同一量 に於て INAHに比しやや劣る点もあるが大体に於 ては近似の効果を示している.

\section{第 4 章 部括並ひに考按}

或る種の薬剂から種々の諉導体が改良合成される 事により新䌘品が元の性状より，ょり安定で副作用 す減し，薬理作用手增强されて来た例は古今その例 が多々ある。本実験の INHG はそのような意味で 作られた INAH の新誘蒌体であるが，その基礎実 験が未た確立されていないので，私はマウスを用い， はじめて系統的基碄実験を行い同時に INAH, IHMS との比較検討を毛行つた。

INHG は緒言で述へた如く，ラクトン型のクル クロン酸でイリニコチール・ヒドラソンを縮合した あのである.なおグルクロン酸は1878年 Jaffe $\mathrm{e}^{9)}$ に よつて報告さ机，現在抱合解毒剂として広く宣伝さ れている事は衆知の事である.

さて1952年 Passedouet17) 等は INHG を合成し， 引続いて Brouet334) 等によつてラッテ，モルモ\% トの実験を行い，本剂が実呀的結核症を阻止する力 を有すといい，その作用は単にその中に含有する INAH を遊離するのみでなくクルクロン酸成分が 作用する事によつて，INAH の菌被膜の贯通が容 易になる事及びヒドラジンがヒドラソンに变つた事 等にもよるものであろろ上述へているが，氏等の実 験は実は剖検所見のみによるるので，斯かる治㞠実 験に最も重要なる極手である臟器結核菌定星培蓄を 意つているので, 果して確実に本剂が有效か否やを 直ちに決める事虫出来ない，即ち実験的結校症に対 する治療効果の判定については，岡等16)が述へてい 万如く, 組織又机媵器に肉眼的に見得る結核性病变 の量とその中に含まれている生きた結核囷の数とは 必ずしも並行しない，又化学療法である以上，体邖 で結核菌を直ちに死隇せしめないとしても，少くと 6比较的短期間内に菌の繁殖が阻止される事が証明 されないと有効とはいえない，特に結核病变は自然
後退の傾向が大きいから，培蕌に上つて生菌の検索 老行万事は効果の判定上非常に大切な舟之なる。

そこで私はマウス実験的結核症に刘するINHG

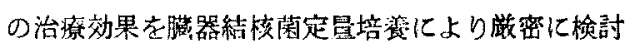
世んと企てた。

又本㥔の毒甠については Brouet3) 等は $20 \mathrm{~g}$ の

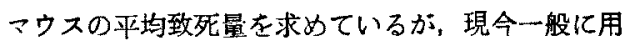
いられている $10 \mathrm{~g}$ のマウスに对する平均致死量は 全々求めら机ていないので, 私は本研究に於て之も 併せ袷討した。

先つ英䇤試験について総括するに，私は $10 \mathrm{~g} の$ アウスの平均致死星估 INHG 皮下注射 $1167 \mathrm{mg} / \mathrm{kg}$, 経口投与 $1500 \mathrm{mg} / \mathrm{kg}$ である事を認めた。先に述 へた如くBrouet3) 等は $20 \mathrm{~g}$ のマウスについて 平均致死量を求め, 経腹膜 $1500 \mathrm{mg} / \mathrm{kg}$, 経胃 $1250 \mathrm{mg} / \mathrm{kg}$ といつているが, $10 \mathrm{~g}$ のマウスにつ いては行っていない，次に対照として行つた INAH の平均致死量は皮下注射 $141 \mathrm{mg} / \mathrm{kg}$, 経口投与 $167 \mathrm{mg} / \mathrm{kg}$ であるが, 之は Benson2) 等の皮下 $160 \mathrm{mg} / \mathrm{kg}$, 経口 $142 \mathrm{mg} / \mathrm{kg}$, 静拄 $157 \mathrm{mg} / \mathrm{kg}$, Rubin 19) 等の皮下 $170 \mathrm{mg} / \mathrm{kg}$, 経口 $190 \mathrm{mg} / \mathrm{kg}$ という報告, 又邦製 INAH 16 種類についての柳 沢22) の皮下 142 187 mg/kg という埌告（厚生省 結核寮法研究協議会報告のまとめ) と大差がない.

次に同じく刘照として行つた IHMS の平均致死 量は皮下注射 $1083 \mathrm{mg} / \mathrm{kg}$, 経口投与 $1333 \mathrm{mg} / \mathrm{kg}$ であり，圾本202の皮下 $1106 \mathrm{mg} / \mathrm{kg}$ という報告と ほほ一致した。

このようにして私の実験では INHG のアウス平 均致死量は IHMS の夫れより少し高いが，いつれ も INAH の䚾 6〜8倍に及び，従って毒性は INAH の1/6〜1/8 であるといい得る.

なお INAH 急性中毒症状として Benson2)はマ

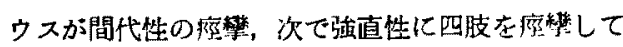

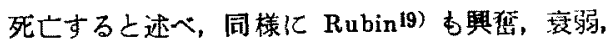

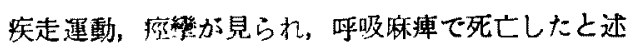
ヘており，このように一般に INAHには中枢神 経5(6)7)21)及び末梢神経(1)12) 亿対す万作用がある事 が知られているが、私の错察したINHG，IHMS の急性中毒症状が前述の如く INAH のそれ上似て いるのは縮合物としての中毒というよりも INAH 中䇙症状が主となるためであるう。

さて次にマウス結核症に対する治療英験を総括す るに先つ第一実験では INHG $1 \mathrm{mg}, 3 \mathrm{mg}, 7 \mathrm{mg}$ 投与群とも，剖俭所見では結核性病変が対照に比し 


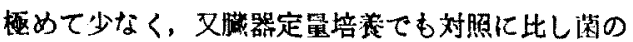
発育は極めてわすかであつた，即ち INHG のマウ ス実駼的結㯖症に対する治療效果は㥛りて著明であ る事が判明した。

次第二实験では，投与最を一酋诚少して INAH の效果と比校したのであるが, INHG $5 \mathrm{mg}, 1 \mathrm{mg}$,

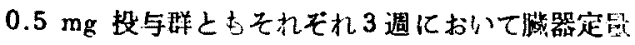
培責上，各满器とす全て陰性であり，6週には $0.1 \mathrm{mg}$ 投与群む陰些となつた。 こ机に対して

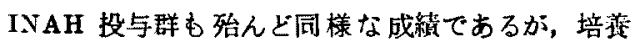
陽生の部分を比校するならば, INAH 治療群の方 が幾分登現集落数が少なかつた，従つて本実験では

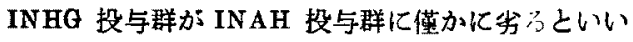
得る。しかし之は INHG に含まれる INAH は 44.62\%である事を思えばすとより当然で，むしろ てのように INAH に接近した成續の得ら机る事は， INHG の効力が単に INAH のみによるもので無い 事を示しているといえよう.

なおマウスでは血沈，体温等に対する影響を見る ヘくるないが，体重に対し INHQ は INAH 上り 良好な影響を及恬した。即ちこの事は前述の如く本 剂の毒性が INAH に比し楆めて低い（マウスで1/6

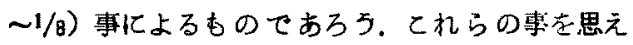
ば本剂のかなりの大冒投与が可能と思われ, 從つて 実際的には以上の定量培羡の成箖はさらに高く期待 されてよいるのと思われる，但しもとより動物実験 の成績をむつてそのまま臨床にあてはめる事は危険 で，その間に充分なる考虑を要する事が必要である.

次比耐性発哯の問題であるが INAH の新誘導体 である INHGは当然, 耐性獲得の点でも恐らく INAH と同様古態度を示すであるうと思われる。 この点については教室吉川233，影山103の研究があり 教室大藤13）等は臨休的に INHG 耐性菌の出現を 認めている。而し本実験では 6 週の治療期間であり， 使用薬剂の総量も 1 匹当り, 最高 $0.2 \mathrm{~g}$ 程度であ つたので耐炇菌の出現を認める事は出来なかつた。

最後に INHG の効力を IHMS のそれと比較す るために IHMS についてもマクスを使用して経口 及び皮注投与により治㙩したが，先に述へた如く剖

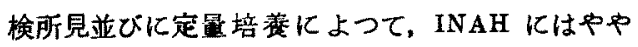

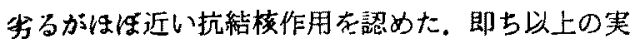
跧成綪から両者を比较檢討するに，まず Ld（50）

\section{文南京}

1) Benger : Dtsch. med. Wschr., 78, 1459, 1953.
は前述の如く共に INAH の $1 / 7$ 程度であり，野物 契験については培望所見を比较すると，多少 IHMS の方が上いようであるが，著明な差ではない．

以上から結䄖的にいつて INHG は实験的結模 症に対して IHMS とほほ同等の効力があり、又

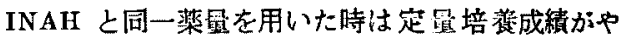
や劣るが，毒性が INAH の $1 / 7$ であるので大冒投 与が可能であり，臨床的にはさらに強力な効果が期 待され得るものと考えられる。

\section{第5 章 䊅語}

INAH の新誘導体である INHGについて，てれ まで行わ机ていない所の実験的結核症に対する確実 なる治療効果を检討し，併せて莺性をむ再吟味し， 次のような結果を得た。なお INAH，IHMS を対 照として使用し比較梌討した，

1) INHGの10 g のマウス皮下注射 Ld (50)は $1167 \mathrm{mg} / \mathrm{kg}$ ，経口投与 $1500 \mathrm{mg} / \mathrm{kg}$ であり, IHMg の皮下注射 Ld (50)は $1083 \mathrm{mg} / \mathrm{kg}$ ，経口投与 $1333 \mathrm{mg} / \mathrm{kg}$ であつて, 共に INAH の約 $6 \sim 8$ 倍 注相当し，毒性が著しく少い。

2）結核䍜患マウスに対し，INHGを $1 \mathrm{mg}$ $3 \mathrm{mg} ， 7 \mathrm{mg}$ それそれ連日投与すると，縢器内結 核消は对照汇比し著しく少なくなり，本霍の抗結椟 作用の著明な事が確認された。

3) INHG とINAH のマウス実験的結核症に対 する勃果を比较検討すると，INHGはINAHを 44.6296含有するのみであるにもかかわらす埛器結

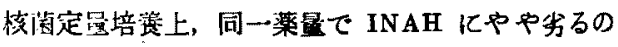
みで大差なく，しかす体重增加作用は INAH 上り 强い，更に又 INHG は，前述の如くその毒性が梀 めて小さいので大叟投与が可能であり，臨床上更に 著しい效果が期待出来る。

4) INHG とIHMS のマウス実験的結核症に対 する効果を比较検討すると，両者の間には著明な差 はなかつた。

掘筆に臨み御指導御校閲を賜わつた恩師平木教授

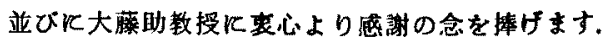

（本論文の要旨恬柖和30年 4 月第30回日本結核病 学会総会に於て発肃した)

2) Benson-Am. Rev. Tbc., 65, 376, 1952. 
3) Brouet, et al : Revue de la Tbc., 17, 789, 1953.

4) Brouet, et al : Presse. med., 61, 863, 1953.

5) Conrad : Dtsch. med. Wschr., 78, 604, 1953.

6) Hunter : Lancet, X III-6742, 960, 1953.

7) Irving : Am. Rev. Tbe., 67, 212, 1953.

8）岩崎竜郎他 . 日本臨休結核，11，430, 昭27.

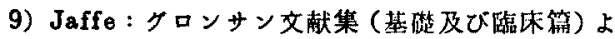
り引用，中外製薬学術課。

10）景山統二郎：岡山医学会椎誌, 近刊.

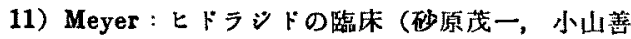
之共著）より引用, 中外医学社, 昭27.

12) Narld : Am. Rev. Tbc., 68, 458, 1953.
13）大藤具他：結核，墦刊，198，昭30

14）小川辰次：結校，24，45，昭24。

15）小川辰次 - 結技，24，403，昭24。

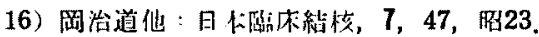

17) Passedonet, et al : Revne de 1a Tbc., 17, 789, 1953.

18) Peter, et al.J. Am. pharma. Assoc., 10. $612,1953$.

19) Rubin : Am. Rev. Tbc., 65, 392, 1952.

20）坡本立身：結核，30，24，昭 30 .

21) Stadler : Dtsch. med. Wschr., 78, 612, 1952.

22）柳沢举、日本医事新報，1516，1887，昭28。

23) 吉川潔 : 岡山医学会雑誌, 近刊。

\title{
Treatment of Experimental Tuberculosis with INAH Derivatives
}

\author{
Part 1. Acute Toxicity of Isonicotyl Hydrazone Glycuronolac- \\ tone (INHG) on Mice, and Treatment of \\ Experimental Tuberculosis
}

\author{
By \\ Miyokichi YAMASHITA \\ Department of Internal Medicine Okayama University Medical School \\ (Director; Prof. Kiyoshi Hiraki)
}

In the study on the definitive therapeutic effects of INHG, a new derivative of INAH, on experimental tuberculosis, hitherto no attempt has ever been made, and also in the reappraisal of toxicity of INHG, the author obtained the following results. INAH and IHMS (isonicotyl hydrazid methansulfonate) were used as the control for comparative study:

1. LD50 of INHG, when subcutaneously injected, is $1,167 \mathrm{mg} / \mathrm{kg}$, and when orally administered, $1,500 \mathrm{mg} / \mathrm{kg}$; while LD 50 of IHMS, by subcutaneous injection, is $1,083 \mathrm{mg} / \mathrm{kg}$, and by oral administration, $1,333 \mathrm{mg} / \mathrm{kg}$. Each of these amounts to $6-8$ times $L_{50}$ of IHAH, proving the toxicity of the two to be markedly lower than INAH.

2. When $1 \mathrm{mg}, 3 \mathrm{mg}$, or $7 \mathrm{mg}$ of INHG a day is administered successively to mice with tuberculosis, tuberculous bacilli in the viscera of these mice decrease far more markedly than the same in the control, proving a striking anti-tuberculous action of this drag.

3. On coparing the effectiveness of INHG on experimental tuberculosis with that of INAH, in tuberculous bacilli culture of internal organ, even though INHG contians only 44.62 per cent of INAH, an equal volume of this drug is only slightly inferior to INAH but shows no great difference, while its weight-increasing action is stronger than INAH. In addition, the toxicity of INHG being extremely weak as already mentioned, a large dose of 
administration is possible, and hence clinically the application of this drug offers a promising future.

4. In comparing the effectiveness of INHG on the experimental tubereulosis with that of IHMS, no marked difference can be found between the two drugs. 